\title{
Simply Reproducing Reality- Brecht, Benjamin, and Renger-Patzsch on Photography
}

Carl Gelderloos

\section{ABSTRACT}

This article reads Albert Renger-Patzsch's photographic theory and practice in the context of Benjamin's and Brecht's dismissals of his work in order to recover the paradoxical interplay between documentation and perceptual training central to debates about photography as a specifically modern medium during the 1920s. I argue that, rather than evincing a naïve faith in verisimilitude, Renger-Patzsch mobilized ideas of visual analogy, formal play, and embodied vision to foreground the camera's potential for disrupting perceptual habits. Returning to this moment of Weimar photographic theory can help recover deeper aesthetic tensions among formal, documentary, and critical demands made of the medium.

“The situation thus becomes so complicated that a simple 'reproduction of reality' is now less than ever able to say anything about reality. A photograph of the Krupp works or the AEG shows almost nothing about these institutions."

"Only slowly does the much more radical view begin to take hold-that the task of reforming our entire aesthetic perspectives from the ground up falls to this new beauty of technology. ... Works of technology should not conform to an existing aesthetic, but rather, it is through them that our concept of beauty takes on a fundamentally altered aspect." ${ }^{2}$

"But now follow the path of photography further. What do you see? It becomes ever more nuancé, ever more modern; and the result is that it can no longer record a tenement block or a refuse heap without transfiguring it. Needless to say, 
photography is unable to convey anything about a power station or a cable factory other than, 'What a beautiful world!””3

"With the attempt to represent an idea, photography transgresses the borders marked out for it."

The distance between these positions marks out the space of a central debate on photographic representation during the Weimar Republic. The question of photography's capacity to access reality was a keynote of the discourse on the photographic medium in the Weimar Republic. Photography, though nearly a century old by this time, was central to the aesthetic discourse of the 1920s. On the one hand, its mechanical reproduction of visual impressions made it foundational for discussions of the new medium of film, especially before the advent of sound film, and on the other, its supposed documentary veracity prompted reexaminations of older media such as literature and painting. ${ }^{5}$ Because the discussion of photography involved a reappraisal of a medium that was coded as particularly technological and because discussions of photography tended never to remain discussions simply of photography, but also spilled over, particularly under the sign of Neue Sachlichkeit, into other media such as film, literature, and theater, not to mention other conceptual realms entirely, a closer look at a key moment of this debate is a prerequisite to understanding how discourses of technology, media, and aesthetics were constantly reconfiguring and reconstituting each other during the period. ${ }^{6}$

With this paper I hope to reexamine the indirect debate on photographic representation staged by Bertolt Brecht, Walter Benjamin, and Albert Renger-Patzsch. This will involve a good deal of reconstruction and, to be fair, a bit of construction as well, since it was not actually a debate in any meaningful sense of the word. While Benjamin and Brecht do mention Renger-Patzsch explicitly, they address the photographer's work only obliquely and dismissively; it is fair to say that "Renger-Patzsch" or Die Welt ist schön (The World is Beautiful) — the title of his best-known photobook—came to stand in as a synecdoche for the photography of Neue Sachlichkeit more generally, and even for broader tendencies or possibilities of photography at large. Renger-Patzsch for his part never addresses either Benjamin or Brecht, and I have been unable to determine whether he was even familiar with their criticisms. His own writings on photography are largely of a practical nature and consist far more of tips for amateurs and professionals on composition, equipment, technique, filters, chemicals, proper tripod usage, how best to illuminate succulents, etc., than the sort of media-theoretical and aesthetic questions Benjamin and Brecht were addressing. But it may be the very fact that the two camps were talking completely past one another that makes this debate so interesting, and it is worth asking what it might mean that two of the most significant media theorists of the Weimar Republic had so little common discursive ground 
with its most prominent photographer and their main target. In effect, Benjamin and Brecht were rejecting, in their various critiques of Renger-Patzsch, the claims of Neue Sachlichkeit to precision, objectivity, and veracity. ${ }^{7}$ Where Neue Sachlichkeit broadly advanced an aesthetics that bestowed the photograph with the status of meaningful, objective evidence of real-world phenomena, its critics condemned claims such as these as naïve realism.

Yet without muting the force of Benjamin's and Brecht's criticisms, I would nevertheless like to suggest that their objections are not of necessity directed specifically at Renger-Patzsch: Indeed, with a shift or two of rhetorical emphasis, the photographer's work could have been the object especially of Benjamin's praise, as was RengerPatzsch's colleague Karl Blossfeldt. It should be clear from the start that neither side upheld an aesthetics centered primarily on the category of the beautiful, as did the pictorialists: Like Benjamin and Brecht, Renger-Patzsch was interested in the ways that photography could train a new kind of perception. Neither was he invested in upholding inherited ideas of art or beauty, and indeed, he explicitly bracketed out the question of whether photography could be considered art. ${ }^{9}$ Nevertheless, RengerPatzsch came to serve as a necessary placeholder of sorts, a provocation and an aid to navigating the ambivalence of the photographic medium. In this vein, it is perhaps not too much of a stretch to say that if Renger-Patzsch hadn't existed, it would have been necessary for Benjamin and Brecht to invent him. Thus-inversely—another look at the indirect debate on photography amongst Benjamin, Brecht, and RengerPatzsch might provide the leverage needed to pry open the ambiguities in Benjamin's and Brecht's own conceptualizations of the medium.

At issue is not just a disagreement on the ins and outs of photographic representation, but competing paradigms of the relationship between surface appearance and reality and, by extension, divergent discourses on technology. The photograph became, in the media-theoretical discussions of the Weimar period, an arena for working through questions of the adequate representation and meaningful knowledge of reality, well beyond more modest questions of visual resemblance or verisimilitude. Photography was able to serve as the flashpoint for social and aesthetic debates about technology, representation, and knowledge largely because of larger questions concerning Neue Sachlichkeit. ${ }^{10}$ Neue Sachlichkeit provided a framework for thinking about photographic realism, yet no clear way for unambiguously determining what this realism might or should entail. In part then, the differences between Benjamin's, Brecht's, and Renger-Patzsch's views of photography stemmed from their divergent understandings of aesthetic realism, and what exactly might be involved in representing reality.

Renger-Patzsch's 1928 photobook, Die Welt ist schön, is a collection of one hundred black and white images, each presented in numbered sequence without caption on a single recto page of the volume, facing a blank verso page. A table of 
contents identifies each image concisely, naming the depicted object or landscape and only rarely giving geographic information. While Carl Georg Heise's introduction organizes the book into eight thematic sections ("Plants," "Animals and People," "Landscape," "Material," "Architecture," "Technology," "Colorful World," and "Symbol"), the collection proceeds by formal rhyming and visual analogy as much as it moves thematically from one image to the next. ${ }^{11}$ Through careful composition and lighting Renger-Patzsch is able to isolate striking formal aspects and visual details of such diverse subjects as agave, sheep, coffee beans, human faces, the rooftops of Lübeck, industrial forges, gear belts, sludge tanks, and much else. This encyclopedic inclusiveness, isolating disparate objects from their contexts and uniting them all, without explicit commentary, as objects of aesthetic appreciation under the title "Die Welt ist schön," earned Renger-Patzsch the accusation of Verklärung, or aesthetic transfiguration.

Brecht refers to Renger-Patzsch in a 1928 fragment called "Über Fotografie" (On Photography). Criticizing photography's unwillingness to move beyond displays of technical proficiency and attempts to mimic painting, he charges avant-garde photography with an obsessive and fetishistic focus on visual appearance: "Often, such a naïve question emerges from the pictures of the avant-garde: 'Do you know what a woman's bottom looks like, no, I mean what it really looks like?'"12 Yet the obsession with the visual is not Brecht's primary gripe with the photography of the avant-garde or of Neues Sehen, but rather the suspicion that it is a disingenuous obsession, in that its true object is not a renewed confrontation with visual appearance at all, but rather a roundabout preservation of an aestheticist conception of art. "That alone wouldn't be off-putting," continues Brecht, "if one didn't have the impression that they aren't even that interested in the answer to this modest question but rather in the fact that an art work arises, something that uses this bottom as a mere occasion. The main point is probably to show that "life is indeed beautiful"" ("Es handelt sich hauptsächlich wohl darum, zu zeigen, daß 'das Leben doch schön ist'”).

Brecht's rendering of Renger-Patzsch's title is telling, and it is tempting to say that Brecht has transfigured the title of the photobook into what he sees as its essential enunciatory force: where "Welt" might be taken in a more neutral sense as referring to the world of possible images, "Leben" suggests a glib judgment on social actuality, reinforced by the way the "doch," in foregrounding the question of beauty, serves as the programmatic gesture of Verklärung. In a 1930 fragment, Brecht elaborates on the connection between photographic reproduction and Verklärung, echoing the first epigraph above: "Photography is the possibility of a reproduction ["Wiedergabe"] that plasters over the context. The Marxist [Fritz] Sternberg... explicates that no insights can be won from a (precise) photograph of a Ford factory." 13

Photography by its very medial nature has the possibility to extract visual data from a given social and historical context and present it in isolation, as a static, supratem- 
poral image; for Brecht and Benjamin, the contemporary tendency represented by Renger-Patzsch makes this moment central. Benjamin:

The World is Beautiful - this is the title of the well-known picture anthology by Renger-Patzsch, in which we see New Objective photography at its peak. For it has succeeded in transforming even abject poverty—by apprehending it in a fashionably perfected manner-into an object of enjoyment. For if it is an economic function of photography to restore to mass consumption, by fashionable adaptation, subjects that had earlier withdrawn themselves from it (springtime, famous people, foreign countries), it is one of its political functions to renew from within - that is, fashionably—the world as it is. ${ }^{14}$

Thus it is not simply that photography removes the photographed object from its historical context, thereby obscuring this context; for Benjamin, it has the additional function of repackaging existing reality ("the world as it is") in modish luster, turning the photographed object into an object of consumer pleasure. That which exists is sold, with photography's help, as something new. This is, of course, the logic of the advertisement, and Benjamin had linked photography, fashion, and advertising in his earlier "Kleine Geschichte der Photographie," where his target is likewise Albert Renger-Patzsch: "But because the true face of this kind of photographic creativity is the advertisement or association, its logical counterpart is the act of unmasking or construction." ${ }^{15}$ To be sure, many of the images in Die Welt ist schön were produced for industrial and commercial clients, and the relatively new medium of advertisements illustrated by photographs certainly informed contemporary discourse on photography. ${ }^{16}$ Yet even if we bracket out the question of advertising and the ready judgments on consumer culture that may accompany it, it is clear that for Benjamin and Brecht the photographic surface itself obscures an underlying reality rather than providing access to it, as it supposedly does for Renger-Patzsch.

It is therefore worth mentioning that Benjamin's argument that the economic role of photography is to offer the consumer images of commodities not actually attainable presages John Berger's claim in Ways of Seeing (1973) about the historical affinity between the rise of European oil painting and that of commodity capitalism. ${ }^{17}$ Indeed, the commodity is an important if never fully visible term in Benjamin's and Brecht's critiques, and the charge that the image obscures rather than reveals a functional reality bears strong similarities to a basic Marxian dynamic: the relationship between surface appearance and underlying reality, perhaps most well known from the discussion of commodity fetishism in volume 1 of Capital. The commodity is a fetish, for Marx, because it obscures the social relations that produced it; it is the tangible evidence of a complex, particularly historical system, and yet it seems to be merely an object. In Marx's formulation, "It is nothing but the definite social 
relation between men themselves which assumes here, for them, the fantastic form of a relation between things." 18

So the problem for Benjamin and Brecht is not just that photography can make the ugly beautiful nor even that it transmutes social or political concerns into aesthetic ones, but rather that, in so doing, it recapitulates an essential logic of capitalist modernity. If reification or Verdinglichung obfuscates the complex social relations of production behind the deceptive self-evidence of a world of commodities, Verklärung obstructs access to functional social realities by presenting a world of things made beautiful. In this context, Verklärung for Benjamin and Brecht is not the necessary transfiguration of real-world material into a presentation suitable for an aesthetic medium, but is rather the obscuring aestheticization of complex social realities, performing on the level of images what Verdinglichung achieves on the level of things. ${ }^{19}$ Thus the problem with Renger-Patzsch's photography for them is not just that it makes commodities beautiful, but that it duplicates the logic of the commodity fetish itself. In Brecht's Dreigroschenproze $\beta$, we read: "The situation thus becomes so complicated that a simple 'reproduction of reality' is now less than ever able to say anything about reality. A photograph of the Krupp works or the AEG shows almost nothing about these institutions. Actual reality has slipped into the functional dimension. The reification of human relations, such as the factory, for example, no longer surrenders the latter." ${ }^{20}$ Closely related to the accusations of Verklärung is the idea that the photographic image obscures the underlying reality. Contrary to a logic of physiognomy, which holds that visible form is an expression of a deeper truth of being, the surface tells us nothing about the interior, and the image is helplessly mute. A reproduction of visual appearance is just that - a doubling of visual appearance that offers no new insight into an already mystified and mystifying social order. For Benjamin, the photographic tendency represented by Renger-Patzsch senselessly reduplicates the world of commodities, thereby obscuring any possibility for a deeper recognition of the human context behind those commodities: "In it [i.e., in the motto "Die Welt ist schön"] is unmasked the posture of a photography that can endow any soup can with cosmic significance but cannot grasp a single one of the human connections in which it exists, even when this photography's most dream-laden subjects are a forerunner more of its salability than of any knowledge it might produce." ${ }^{11}$ The photographic image thus recapitulates a logic of commodification on multiple levels.

For Brecht and Benjamin, then, Renger-Patzsch is both symptomatic and symbolic of photography's innate capacity for Verklärung -in its essentially myopic focus on yielding up an aesthetically pleasing visual surface, it both distracts from and obstructs meaningful insight into the photographed object. In retrospect, it seems inevitable that Renger-Patzsch should have come to play this role. Die Welt ist schön was a wellknown work, ${ }^{22}$ and had its popularity, glossy images, and implicit unifying narrative not sufficed to earn it a representative status in late Weimar debates of photographic 
representation, the programmatic title alone may have been enough to guarantee it that role. Yet as has often been pointed out, "Die Welt ist schön" was not RengerPatzsch's choice of title, but that of his publisher, Kurt Wolff. The photographer's own preferred title for his book was allegedly "Die Dinge" - one might imagine, all other things being equal, that such a title would have been far more sympathetic to Benjamin and Brecht than the more saccharine moniker that ended up gracing the collection's cloth spine. It would be tempting to explain away their criticisms of Renger-Patzsch as the result of a misunderstanding, but this would be inadequate. Renger-Patzsch's book, once in circulation under its more marketable, innocently provocative title, was no longer a collection of technically superb photographic studies of various objects, but itself an object, participant, and prompt in the contemporary discourse on the photographic medium.

And regardless of whether it had been dubbed "Die Welt ist schön," "Die Dinge," or anything else, the photographic practice it demonstrated represented an irritation for a critical photographic theory. Brechtian-Benjaminian hackles would have been raised, I propose, whatever the title of Renger-Patzsch's photobook. This is not because his photography was simply incommensurable with their views of the medium's potential-I don't think that it was-but because of a fundamental ambivalence within contemporary photographic discourse between what we might provisionally dub its formal/pedagogical and its documentary/realist emphases. Both bear upon the question of photography's relationship to technology: on the one hand, the program of Neues Sehen foregrounded the medium's capacity to expand and train human perception in a way that fit with the rapid social and technological changes of the period. Photography, like film, was lauded as a medium that was up to the task of refunctioning human sight in an age of radical industrialization and urbanization. On the other hand, photography's putative mechanical exactitude inspired a whole body of claims and counterclaims about the camera's superior representative potential. The tension between these poles has its counterparts in Benjamin and Brecht, but before addressing the ambivalence between photography's various facets in their work, it will be useful to turn to the theoretic writings of Renger-Patzsch.

To be sure, Renger-Patzsch was interested in photography's ability to reproduce ("wiedergeben") a visual scene. But his understanding of what exactly constituted a photographic Wiedergabe differed from the simply positivistic notion implied by Brecht's critique in the Dreigroschenproze $\beta$, as did his conception of what photography could and should portray. For Renger-Patzsch, the photographic image was neither merely an immediate reproduction of a visual impression, nor did photography aspire towards enunciatory force concerning functional social realities. Just as he bracketed art out of photography's purview on the one side, he denied it access to discursive or conceptual claims on the other: "With the attempt to represent an idea, photography transgresses the borders marked out for it," as he writes in a 1961 essay called "Über 
die Grenzen unseres Metiers. Kann die Fotografie einen Typus wiedergeben?"23 In this sense, Renger-Patzsch and Benjamin and Brecht are talking past each other; since they disagreed on the very premises of what photography was and what it should be, they lacked the common ground upon which to work out how it could achieve its aims. In a sense, this is simply another way of stating the obvious - that Benjamin and Brecht approached photography as critical media theorists while Renger-Patzsch spoke as a Berufsfotograf. Nonetheless, what is interesting is the way that both camps came up against the same ambivalences of the medium, each working in his own specific idiom.

Straight theoretical pronouncements from Renger-Patzsch are few and far between. The casual reader of Die Freude am Gegenstand, a recent collection of Renger-Patzsch's writings on photography, will immediately notice the prevalence of purely technical insights. Many of Renger-Patzsch's pieces were written for other photographers, and often directed towards enthusiastic amateurs seeking to hone their landscape or botanical photography skills. There are a few pieces that enter the discursive fray and address photography as a medium, such as "Ketzergedanken über künstlerische Photographie," "Photographie und Kunst," and "Ziele." Yet even in the more technical texts it is possible to discern an implicit engagement with the questions being posed of and by the medium during the 1920s.

Photography indeed served a documentary purpose for Renger-Patzsch, but it was to document not simply reality at large, but rather forms per se. The Wiedergabe at stake was a reproduction of visual forms and, by way of these, sensory experience. As Claus Pfingsten has noted, "This claim of photography's to a documentation of reality is realized by the photographer by taking inventory of and exactly reproducing forms." ${ }^{24}$ Yet as Bernd Stiegler has pointed out, even within the claim to exactly reproduce forms-what has often been called Renger-Patzsch's realism-there lies a tension between the exact depiction of an object and formal play for its own sake, between identification and resemblance or visual analogy. ${ }^{25}$ Because Renger-Patzsch was not photographing with an eye towards the identification of an object or scene but rather to draw out salient formal features, his more technical writings emphasize the initial composition of an image and its subsequent cropping in the darkroom. Thus to take an example emphasized by Thomas Janzen, an image that depicts an immediately recognizable quay wall above a canal is cropped to become the diagonal intersection of two surfaces - the stipple of brick and the ripple of water ${ }^{26}$ In Stiegler's formulation, "scarcely any photographer of his time so fully committed himself to the world of things as he, yet also hardly any carried formal abstraction as far as he did."27

The tendency towards formal play distances the photograph from any simple identificatory function that might be anticipated by the idea of Wiedergabe, and enables the photographed subjects to mingle more freely; natural and technological forms, for example, come to resemble one another. ${ }^{28} \mathrm{~A}$ close-up of a snake's scales produces the 
formal repetition and burnished hardness of a machine, while images of industrial forges or warehouses take on an organic, creaturely quality. As Bernd Stiegler writes,

His concept, which as he understands it ties art and handicraft, nature and culture, subject and object, technology and flora to each other, is form. Form is in his photographic theory and praxis the central mediating instance that should serve to neutralize the ambivalence of his images and texts. It should allow him to associate radical modernity and "elementary spaces." Photography is for him the characteristic and particular encounter of the concrete object with abstract form-and vice-versa, the abstract object with the concrete form..$^{29}$

Formal principles allow Die Welt ist schön to move between images of otherwise incongruous subjects, from the North Sea surf, for example, to rows of identical cobbler's lasts, and form for Renger-Patzsch is closely linked to photography's capacity for Wiedergabe - the well-chosen form is what brings the essence of the photographed object to the viewer.

Yet for Renger-Patzsch, Wiedergabe is not merely a visual duplication of what exists, but is rather the recreation of a perceptual experience for the viewer; likewise, the essence ("das Wesentliche") is not conceived as a conceptual or critical knowledge of the object (Brecht's factory, say) but is instead supposed to be a representative moment that makes a particular quality of the photographed subject present for the viewer. In a programmatic essay called "Ziele," Renger-Patzsch speaks in favor of a kind of photographic realism that would be able to reproduce impressions ("Eindrücke") and the "magic of the material" ("den Zauber des Materials"). ${ }^{30}$ The mechanical nature of photography means that it is the medium able to "do justice" to modern technology: "To do justice in the image to the rigid linear structure of modern technology, the airy latticework of cranes and bridges, the dynamics of 1,000-horsepower machines is likely something only photography can do." ${ }^{11}$ Expanding upon this idea in "Photographie und Kunst," he writes:

Thus [the photographer] can in the blink of an eye conjure forth things with which the artist would have to struggle for days on end; not to speak of those areas that are closed to the artist, but in which photography finds itself most at home. Be it as a sovereign ruler of the most fleeting moments or in the analysis of individual phases of quick movement, be it to fix the all too quickly fading formal beauty of flowers or to reproduce the dynamism in the realm of modern technology. ${ }^{32}$

The particular temporality involved in both "fixing" an evanescent moment in a biological process and reproducing technological dynamism is worth noting here; both punctual and sustained, it elicits an elemental dimension common to organic 
life and technological modernity alike. Likewise, the sensory experience that is the goal of Renger-Patzsch's Wiedergabe is the experience of space, motion, and kinetic potential: "One still asks what the tasks of photography are? To capture the height of a Gothic cathedral so that one gets a feeling of dizziness, to capture an automobile, so that one sees its inherent speed, to capture the air, so that one feels the space." ${ }^{3}$

That Renger-Patzsch's Wiedergabe is the recreation of kinaesthetic and sensual experience rather than the duplication of the visible can be seen in his advice to amateur photographers on how to compose a landscape. While the photographic novice immersed in a natural landscape such as the Harz Mountains would tend to photograph a given scene indiscriminately, unwittingly influenced by the various sense impressions - the smell of the air, the vastness of the landscape, the pleasant fatigue of the hike, and so on-that subtly and momentarily contribute to making the landscape noteworthy, the finished photograph of course conveys none of this, and may seem pale and bland in comparison to the original experience. By contrast the more experienced photographer, according to Renger-Patzsch, filters out the other sense impressions and carefully chooses a detail or form in the landscape that captures its particular quality, thus recreating the total sensory experience that the careless amateur, unknowingly influenced by it, actually destroys. ${ }^{34}$ "Whoever knows a landscape must also immediately recognize it in a photograph; whoever does not know it must get the correct idea of it." ${ }^{35}$ When prescribing proper practice for landscape photography, Renger-Patzsch relies on the category of "Ähnlichkeit," but this is no more a simple resemblance to the landscape than "Wiedergabe" is a duplication of the visual. Instead, "Ähnlichkeit" relies on an understanding of the perceived characteristic qualities of a landscape: "We must welcome everything that underscores the particular character; we must condemn the accidental aspects we encounter everywhere." 36

The photographed landscape must therefore resemble an ideal version of the actual landscape, a version that captures its essential qualities. Put this way, this photographic imperative could certainly be understood as the type of Verklärung criticized by Brecht and Benjamin, a smoothing over of the visible surface to make any subject more aesthetically appealing, extracting an "essence" cleansed of its historical and social context to present it as something eternal. But another reading of Renger-Patzsch's landscape advice would see it as the kind of negotiation of the relationship among sense perception, formal play, and new media characteristic of other avant-garde discourse of the time. Discussing a key ambivalence in Renger-Patzsch's theoretical writings between photography's documentary and essentialist aspirations, Stiegler writes, "a photography [conceived] as documentation opposes one [conceived] as gazing upon an essence." ${ }^{37}$ This is an important point, and the two tendencies do exist side by side in Renger-Patzsch's writings without being fully resolved, but one must go further. I would suggest that the tension between documentation and essence 
cannot be fully resolved in Renger-Patzsch's work because they are arguably never entirely distinct from one another. Photographic Wiedergabe is the documentation of an essence. As the advice on composing a landscape suggests, to accurately render the formal and surface qualities of an object is to reproduce "das Wesentliche," and this type of photography, both "Dokumentation" and "Wesensschau," is also a training of visual perception. In other words, to teach the viewer to see the "essential," so little evident in a given photogenic object or scene that the amateur photographer may miss it entirely, is tantamount to training a new sort of perception.

A just recreation of a landscape, a botanical specimen, or a modern machine necessitates a new kind of perception that, in foregrounding salient formal features, breaks with the encrusted habits of an inherited aesthetics that takes its cues from painting. In this regard, Renger-Patzsch's photographic program shared key impetuses with that of László Moholy-Nagy, although his aesthetic strategy and practice were quite different. ${ }^{38}$ Like Moholy-Nagy's 1925 Malerei Fotografie Film, Die Welt ist schön was understood by its author as an "ABC-Buch," a photographic primer intended to train a heightened formal awareness, sharpening the eye to grant it both a renewed perception of natural forms and aesthetic access to modern technology, a point emphasized by Heise in his introduction to the volume. ${ }^{39}$

I have, I hope, sufficiently problematized the self-evidence of certain positions and presuppositions in Renger-Patzsch's photographic practice and theory that we may return to Benjamin's and Brecht's criticisms. Without wishing to reconcile the various complex positions with one another without remainder, it nonetheless seems safe to say that Renger-Patzsch's photographic project was not the glibly aestheticizing replication of surface appearance that their writings seem to imply, but is rather part of a contemporary discourse on perception, technology, and modernity invested in rethinking the possibilities of the photographic medium in opposition to what were seen as inherited, traditionalist, and still culturally dominant aesthetic norms. "Wiedergabe," a term as central to Renger-Patzsch's work as it is odious to Brecht, proves to be a dense concept that is arguably compatible not only with an avant-garde program of Neues Sehen but also with the very compositional principles of construction and dismantling that were key in Brecht and Benjamin's conception of what photography should be. Given the emphasis in Brecht's work, from epic theater to the Dreigroschenproze $\beta$, on making social realities visible, ${ }^{40}$ or Benjamin's praise of the camera's ability to discover hitherto hidden worlds, ${ }^{41}$ it becomes somewhat surprising that they would react so vehemently to a photographer who also thought of his work as perceptual training.

Even the accusation that Renger-Patzsch's photography homogenizes everything it depicts under the rubric of aestheticization, thus eclipsing the social, historical, and economic contexts, becomes less damning when one considers that Benjamin praised another photographer precisely for the way his visual innovations blended natural 
and technological forms. In "Neues von Blumen," a 1928 review of Karl Blossfeldt's book Urformen der Kunst, Benjamin lauds Blossfeldt's detailed photographic studies of botanical forms for expanding the contemporary "perceptual inventory" ("Wahrnehmungsinventar"). ${ }^{42}$ This is striking in light of Benjamin's scornful dismissals of Renger-Patzsch's work, not least because Renger-Patzsch conceived of his own work in similar terms. Benjamin's review continues, in terms that could be applied nearly unaltered to Renger-Patzsch's work:

Whether we speed up the growth of a plant with time-lapse or show its form magnified forty times - in both cases a geyser of new image worlds hisses up from sites of existence from which we least expected it. These photographs reveal a totally unsuspected treasure of analogies and forms in the existence of plants. Only photography is capable of this. ${ }^{43}$

While it might be argued that use of the camera's ability to magnify is what constitutes the difference for Benjamin between Blossfeldt and Renger-Patzsch, since the former's plant photography relied more upon larger-than-life depictions than the latter's, such stylistic details in photographic praxis hardly seem able to account for Benjamin's dichotomous characterization of the two photographers, especially since Renger-Patzsch's photographic theory and practice, with its emphasis on formal analogy and perceptual training, coincided so neatly with precisely those aspects that Benjamin praised in Blossfeldt's work. Even the tropes Benjamin uses to describe the new access photography gives to the forms of the plant kingdom rhyme with RengerPatzsch's own depiction. Where Benjamin writes of Blossfeldt's photographs that "Gazing at them, we stroll beneath these giant plants like Liliputians. To draw all the sweetness from these calyxes/chalices is reserved for great fraternal spirits, sunlike eyes like those possessed by Goethe and Herder," 44 Renger-Patzsch encourages those photographing flowers to see with the eyes of insects: "What is appealing is that, when photographing, one is forced to adjust one's eye to the more or less small organism that a blossom represents, that one is forced, so to speak, to see with the eye of an insect and to make their world our own." 45

Furthermore, the discovery of artificial forms in natural phenomena that Benjamin sees in Blossfeldt's images could be seen as the very program of Die Welt ist schön. The most obvious counterpart to Benjamin's description of this tendency ${ }^{46}$ is perhaps the stylized depiction of an agave plant and a telegraph mast above the monogram on the cover of Die Welt ist schön. Representative of the book's aesthetic program of cataloging visual forms from various realms usually considered distinct, the juxtaposition of agave and telegraph mast is, as Bernd Stiegler points out, by a surprising coincidence replicated in Benjamin's short narrative from 1930, "Myslowitz-Braunschweig- 
Marseilles. Die Geschichte eines Haschischrausches.” Based on a September, 1928 hashish protocol, the text describes a "close combat between telegraph poles and agaves, barbed wire and spiny palm trees" to characterize the "major decisive battle between city and country." ${ }^{47}$

Both resemblance and antagonism, substitution and equivalence, the relationship between the agave and the telegraph masts signals a particular discursive configuration of Weimar culture, a discourse in which nature, technology, perception, and modernity were semantically and conceptually reconstituting and being reconstituted by each other, with no term functioning as a stable or independent variable. In its emphasis on formal play and perceptual training, Die Welt ist schön was no less radical a contribution to this discourse than Benjamin's and Brecht's critiques of it. So what accounts for the vehemence of their dismissals?

I suggested earlier that Renger-Patzsch served as a foil for Benjamin and Brecht, allowing them to work out their own photographic theories, although perhaps "straw man" would be the apter term. Die Welt ist schön could then stand in for the perceived tendency of contemporary photography to conflate unaltered surface appearance with deep structural insight, offering up whatever it photographs in a homogenous and blandly affirmative aestheticization. It should be noted that Benjamin and Brecht were not simply measuring contemporary photographic praxis against the abstract and absolute mandate that it yield immediate insights, and necessarily finding that it fell short, but were rather responding to a prevailing view of photography that attributed to the camera a more immediate access to reality than other media were capable of. Photography's indexicality - the way that the camera produced a record of a given configuration of light in a given place at a given time-granted it in the eyes of many a claim to documentary veracity. In this light, Benjamin and Brecht were each attempting to theorize how photography might regain some of its inherent potential for disruption, against what they saw as the shortcomings of contemporary photographic praxis and theory. ${ }^{48}$ Their strong critiques of Renger-Patzsch and the photography of Neue Sachlichkeit more generally demonstrate a discursive constellation within Weimar discourse consisting of a renewed urgency of the visual, a heightened sense of the political, social, and technological stakes of late capitalism (including the rising threat of fascism), and a rethinking of technology, both as an aesthetic object and as the technological means of aesthetic production that Brecht called the Apparat.

One could speculate that part of the reason for the urgency of the question of photography is that, in the 1920s, the moment of aesthetic production increasingly involved machines on both sides of the equation. As the photographers of New Objectivity flocked to the industrial zones of the Ruhrgebiet and cameras and locomotives found themselves facing one another, older notions of both the artist and artistic material became ever more apparently inadequate. ${ }^{49}$ Just before Brecht's 
criticism in the Dreigroschenproze $\beta$ of photographs of factories, he states that it is more important for a filmmaker to understand his technological apparatus than to aspire to produce "art."

Only in this way can a particular director achieve his "art" in the face of the new apparatuses under the helpful pressure of the sales department: what he achieves is what he himself can make according to his philistine understanding of art. What art should do is something he won't know. ... In the domain of art he exerts the understanding of an oyster, and in the domain of technology it is no better. He is able to comprehend nothing of the apparatuses: he rapes them with his "art." . . . As if one could understand something about art without understanding anything about reality! And here, the apparatus serves as reality at the same time as the subject matter does..$^{50}$

For Brecht, then, reality cannot be understood without an understanding of technology, and crucially, this includes the possibilities of the camera. Far from being exhausted by a reproduction of visual appearance, the camera for Brecht is an instrument of dismantling and construction. Further on in the Dreigroschenproze $\beta$, he writes of the technological progress demonstrated by specific improvements to cameras and film, including increased sensitivity to light and other innovations that facilitate in photographing faces:

But the images one can thus produce are undoubtedly much worse. With the old, less light-sensitive apparatuses, multiple expressions appeared on the plate, which had to be exposed for a fairly long time; in this way, the finite image had a more universal and living expression, and also something of function. . . . The new apparatuses no longer integrate faces-but do they need to be integrated? Perhaps there is a way of photographing, possible for the newer apparatuses, that dissects faces? ${ }^{51}$

The suggestion of a photography that dismantles and analyzes rather than composes is also contained in a short fragment called "Fotografie," probably from 1928, in which Brecht proposes a series of "essential portraits" created by the juxtaposition of multiple images: "A head, captured on different days, in different years. The differences to be brought out. Study of the approximations of physiognomies. A certain number of faces of men and women. Who is married to whom? (One selects those married a long time.)"52 The fragment continues by proposing "functional portraits" of hands - the hands of manual and intellectual laborers each holding the tools of their own trade, and then the tools of each other's trade.

The analytic, dismantling approach to portraiture is reminiscent of Brecht's sus- 
tained critique of bourgeois individuality, whether in the Dreigroschenroman or Mann ist Mann. Echoing the thematic focus in these texts on disassembling and demontage is a program of artistic representation predicated not on reflection but on construction and analysis. "The reification of human relations, such as the factory, for example, no longer yields up the latter. So there is indeed 'something to be constructed,' something 'artificial,' 'contrived.' By the same token, art is necessary." ${ }^{3}$ The artifice of a series of juxtaposed portraits assembled in an experimental vein might thus be able to access levels of social reality that a simple "Wiedergabe" cannot; the implication is that, for Brecht, portraits of hands may well be able to tell us things about capitalist labor where the picture of the factory remains mute. Benjamin likewise emphasizes the constructionist aspect in photography: "But because the true face of this kind of photographic creativity is the advertisement or association, its logical counterpart is the act of unmasking or construction." ${ }_{54}$

Yet the sudden introduction of "Entlarvung," unmasking, complicates things. What is the relationship between unmasking and revealing on the one hand, and construction, artifice, analysis, and dismantling on the other? "Unmasking or construction"- does the "or" mark an apposition or a choice between alternatives? Where Brecht's suggestions for a serial, analytic portraiture imply the centrality of a functional relation, "Entlarvung" suggests at first glance a more immediate and visual access to reality. And if photographic practice is faulted for producing a fetishization of surfaces, what might it mean, concretely, to unmask it, taking the surface off of a surface? While the possibilities of the technological Apparat seen by Brecht and Benjamin in Konstruktion and Zerlegung may well be compatible with Renger-Patzsch's formal play and perceptual training, Entlarvung is an aspect that cannot so easily be meshed with his work, his emphasis on das Wesentliche notwithstanding. If it is still broadly true that, for Renger-Patzsch the visible surface grants access to reality while for Benjamin and Brecht the surface obscures reality, nevertheless the terms have shifted somewhat. The reality accessed by the visible in Renger-Patzsch's work is not an underlying, deep reality but rather an interplay of visual forms able to recreate a sensual, perceptual experience; by contrast, Benjamin and Brecht are now the ones who imply that photography, beyond its contemporary, flawed practice, might yield insights into a deeper functional or structural reality.

Furthermore, what might intuitively seem like contradictory tendencies within each theorist's work are perhaps better described as foundational tensions. On the one hand, Renger-Patzsch's "Wiedergabe" is not a strictly documentary impulse that contrasts with the more avant-garde emphasis on perceptual training but is rather, with its focus on compositional selection and formal interplay, the very vehicle for this training. And in the case of Benjamin and Brecht, Konstruktion, Zerlegung, and Entlarvung are, of course, not in a contradictory relationship either. Brecht's fragment on serial portraiture suggests that dismantling and construction are in fact methods 
for photography to be able to reveal something about reality; the camera for Brecht should be an irritant, and the thrust of his photographic theory was to rethink how the Apparat could break through the glossy veneer spread by a profusion of images and a facilely mimetic photographic practice. ${ }^{55}$ For Benjamin, Entlarvung is not simply unmasking, but is related to a practice of satire and quotation that confronts ideology with its own premises by means of strategic juxtaposition.

Yet while these different photographic possibilities support one another, they still cannot be fully reconciled. Benjamin's praise of the way that Blossfeldt's category of plant forms adds to our Wahrnehmungsinventar cannot comfortably be squared with his accusations of Renger-Patzsch's Verklärung, nor is it apparent that Brecht's proposed essential and functional portraits would actually offer the insight he suggests, given his claim that "anyone who only gives the experienceable side of reality does not reproduce reality itself." ${ }^{56}$ What may ultimately be at issue here is the same tension between the formal and documentary aspects of the photographic image that makes Renger-Patzsch's "einfache Wiedergabe der Realität" not simply a reproduction of reality. At the same time that Benjamin and Brecht rely upon photography's ability to depict visual forms, they also implicitly demand that it be able to make discursive statements about reality.

Significantly, Benjamin and Brecht both suggest Beschriftung, or captioning, as a way out of the impasse of photographic signification, and it is the strategy Brecht will ultimately use in his wartime Kriegsfibel, his most sustained contribution as a photographic practitioner. ${ }^{57}$ The written word is to offer both the clarity and the interruption not, or no longer, accessible to the photographic image alone. Yet inversely, the two theorists draw upon the visual to describe projects in other media. As Steve Giles has pointed out, Brecht uses "abziehen," a verb used to describe the process of printing an image from a photographic negative, to characterize his method in the Dreigroschenproze $\beta$ of bringing bourgeois ideology to light. ${ }^{58}$ And in the same passage he denies revelatory force to a photograph of the factory, Brecht uses "fixieren," which in German as in English can refer to the process of chemically fixing an image on a photosensitive medium, to describe how the new apparatuses (i.e., the camera) could have learned something from the natural sciences about depicting human behavior: "to fix the reciprocal behavior of humans." ${ }^{59}$ So at the same time that the visual image is deemed inadequate to convey discursive meaning, the revelatory or demonstrative function of a text has to draw upon a register of the visual: Put bluntly, the text is to show, make visible, and fix, while the actual image alone seems able to do none of these.

This ambivalence towards the signifying capability of the visual can be situated within the larger context of the contemporary resurgence of physiognomic discourse. Where the camera's mechanical exactitude generated a host of claims about its access to indexical truth, physiognomy linked visual appearance to an underlying reality. As 
argued by Sabine Hake and Matthias Uecker, the Weimar-era photobook often relied upon a physiognomic discourse whereby their photographic subjects were supposed to speak clearly about themselves through the image alone, and yet this project repeatedly ran into the dilemma that the intended unambiguous pronouncement-about an individual, a type, a social group, a historical or political narrative-found itself tripped up by the ambiguous muteness of the image, the slippery relationship between type and mass, or the instability of the very social consensus that originally guaranteed the physiognomic legibility of images. ${ }^{60}$ The visual surface of things that for physiognomy reveals their inner contours remained, frustratingly at times, just a surface. While Brecht and Benjamin responded to this context by rethinking the surface, challenging its putative naturalness by pointing out and recreating its essential constructedness, Renger-Patzsch engaged in the process of exploring the imagistic surface by means of formal analogy, in order to challenge aesthetic and perceptual norms.

Renger-Patzsch's photographic practice and particularly the emphasis in Die Welt ist schön on a formal movement across images from disparate realms both demonstrates the type of perceptual training I have outlined above and undermines the presumption of a static identity between image and reality implicit in the accusation. ${ }^{61}$ In various sequences of Die Welt ist schön, formal elements encourage the viewer to look for forms as such, thereby disrupting the containment within the frame of a single image that would seem to be necessary for the facile aesthetic "reproduction of reality" variously alleged by Benjamin and Brecht. While one can certainly argue that it is precisely this connection across images that enables the uncritical leveling of the visible world in the service of a repressive harmony, Renger-Patzsch's theoretical writings suggest to the contrary (and at times despite themselves) that these image sequences undermine rather than reinforce the apparent self-evidence of the world of things.

A low-angle photograph of the nave of the St. Katharinenkirche in Lübeck (Figure 2), for example, echoes the vaulted arches, serial repetition, and inverted triangle of an array of industrial irons (Figure 1), while the light reflecting off a carefully arranged group at the forefront of the latter suggests the chiaroscuro of ecclesiastical space. On the whole the irons are cleaner, lighter, and more neatly arranged, but the photograph of the church is exposed in a way that both recalls the serial forms of the irons and resembles the bright open spaces of modern design. This formal rhyming, which links the timelessness of a sacred space and the modular, regimented production time of industrial modernity, continues in the next two images, with a prominent diagonal originating in the lower right of the frame and a reconfiguration of similar oblique curves connecting palace steps to the sparse design of a modern ceiling. A similar movement from sacred to profane by means of a shared form can be seen in images 62 to 64, for example, where a gentle baroque curve is stretched and minimalized in the modernist contour of the Fagus factory in Alfeld. To take another 


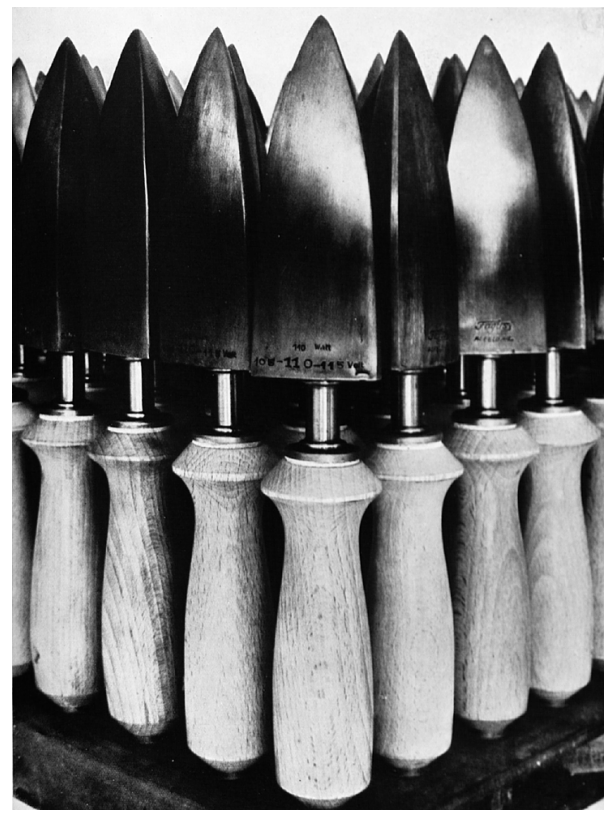

Figure 1. "Bügeleisen für Schuhfabrikation. Fagus-Werk Benscheidt in Alfeld." Albert Renger-Patzsch, Die Welt ist schön. Plate 93. (c) 2013 Albert Renger-Patzsch Archiv / Ann u. Jürgen Wilde, Zülpich / Artists Rights Society (ARS), New York

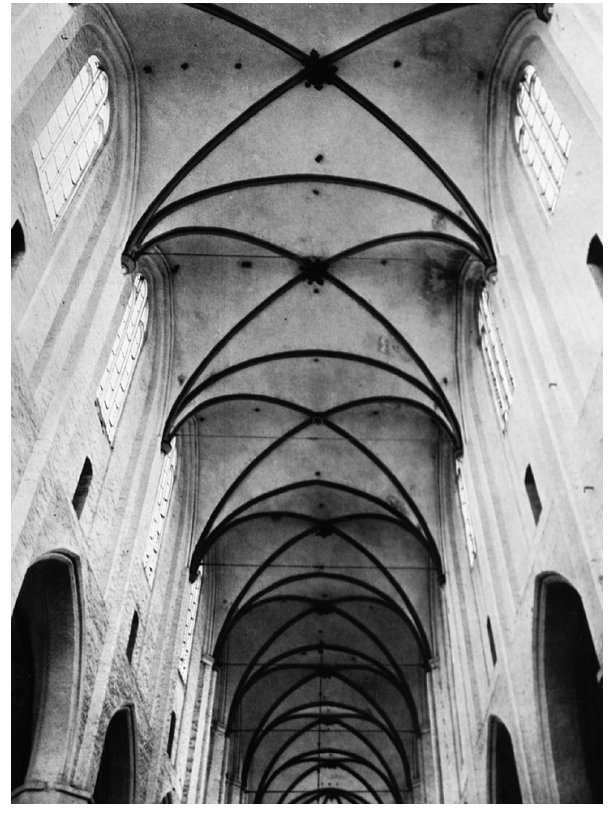

Figure 2. "Gewölbe des Mittelschiffs der St. Katharinenkirche in Lübeck.” Albert Renger-Patzsch, Die Welt ist schön. Plate 94. (C) 2013 Albert Renger-Patzsch Archiv / Ann u. Jürgen Wilde, Zülpich / Artists Rights Society (ARS), New York

example, the struts and supports of an empty Ferris wheel (Figure 5) recall the lines and lattices of a preceding series of images of industrial equipment (Plate 78, and Figures 3 and 4), a point reinforced by the alienating framing and abandoned impression of the ferris wheel. An immediate association provoked by the visual similarity of these machines at rest is the fundamental indistinction between machines that move material for production and those that move people for amusement. This association carries over to the following image of a merry-go-round, where the close cropping, the prevalence of dark tones, and the stony folds of a lowering curtain add up to an eerie stasis rather than pleasant motion - the frozen rictus of the horses suggests the terror of impalement far more than the joy of galloping (Figure 6).

Where this paper began with a hypothetical image of a factory whose visible surface remained mute, perhaps it is fitting to end with two actual photographs of the sea, the guiding image for tropes of visible surface and hidden depths. The first one depicts a scene of rocky surf in the Kattegat, where several ships full of troops sank during the German invasion of Norway. It is the seventh image from Brecht's Kriegsfibel. While there are no people visible in the image, Brecht's quatrain lends voice to a collective speaker beneath the waves: "Eight thousand strong we lie in the [Kattegat]. / Packed 


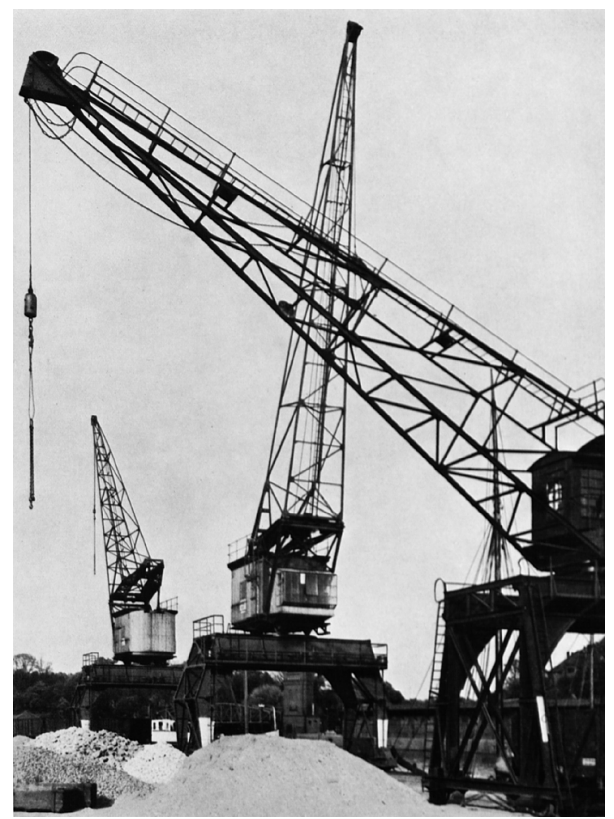

Figure 3. "Kranreihe im Lübecker Hafen." Albert Renger-Patzsch, Die Welt ist schön. Plate 79. ㄷ 2013 Albert Renger-Patzsch Archiv / Ann u. Jürgen Wilde, Zülpich / Artists Rights Society (ARS), New York

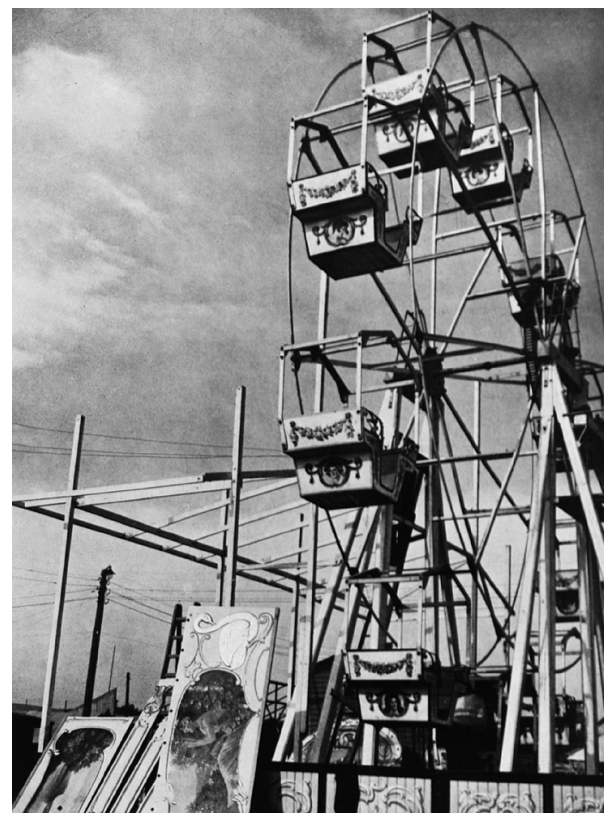

Figure 5. "Russische Schaukel wird montiert." Albert Renger-Patzsch, Die Welt ist schön. Plate 81. () 2013 Albert Renger-Patzsch Archiv / Ann u. Jürgen Wilde, Zülpich / Artists Rights Society (ARS), New York

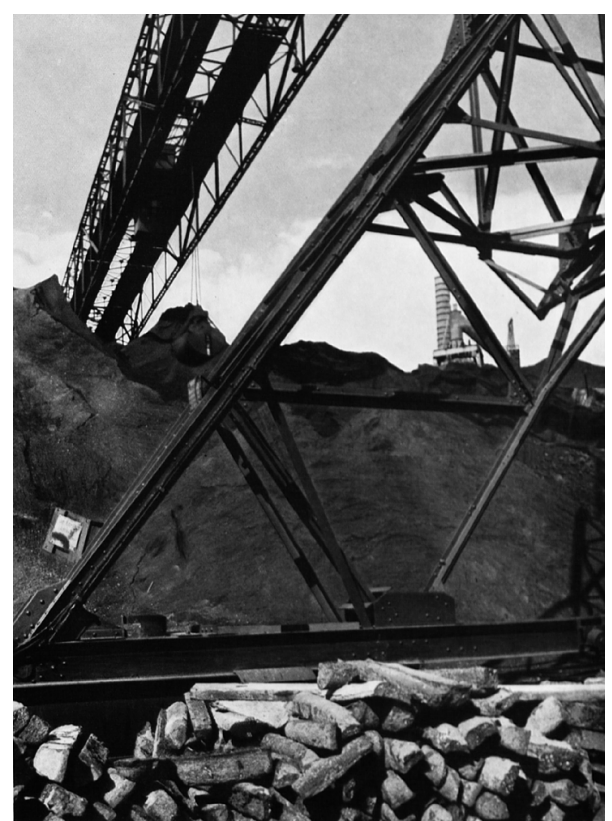

Figure 4. "Laufkran mit Eisenbarren im Hochofenwerk Herrenwyk.” Albert RengerPatzsch, Die Welt ist schön. Plate 80. (C) 2013 Albert Renger-Patzsch Archiv / Ann u. Jürgen Wilde, Zülpich / Artists Rights Society (ARS), New York

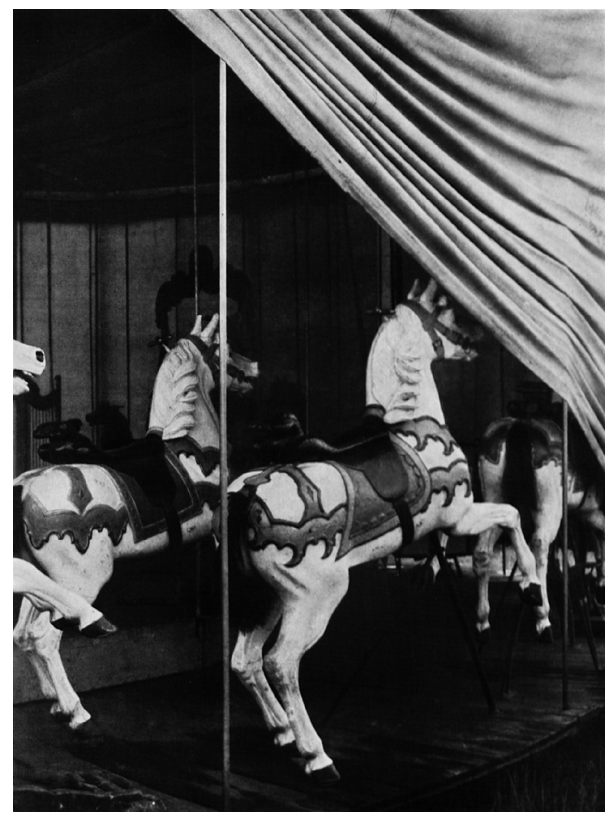

Figure 6. "Karussel." Albert Renger-Patzsch, Die Welt ist schön. Plate 82. (c) 2013 Albert Renger-Patzsch Archiv / Ann u. Jürgen Wilde, Zülpich / Artists Rights Society (ARS), New York 
into cattleboats we crossed the sea. / Fisherman, when fish have filled your net / Remember us, and let just one swim free." 62 The visible landscape is thus shown to be a screen that obscures the real significance of the scene: nature literally covers history. The other image shows surf on a beach in the neighboring North Sea, and it is plate 40 from Die Welt ist schön. There are no words, of course, but the following several images repeat visual elements from the photograph to transform the surface from a natural to a technological one. Plate 41 keeps the pattern of the surf but introduces a diagonal row of wooden pilings; this configuration becomes a rickety wooden walkway over water in the next image, and plate 43 takes up the vertical iteration of the walkway's planks and transforms it into a forest of young beech trees. The multiple vertical elements are preserved in tree shots through 45, whose starkly contrasting pattern of wood and snow becomes a "Fir, bent by a snowstorm;" its stark diagonal on a light background is echoed in the banks of the Trave in 47, becomes a pair of rails in 48 , a quay wall in 49 , and the next image, reversing the diagonal and preserving only the repetition of forms from the brick wall, depicts rows of identical shoe lasts, signaling the thematic transition to a series of architectural and industrial images. Thus in a sense, both Brecht's and Renger-Patzsch's seascapes are able to serve as images of technological modernity; neither photograph lingers in its littoral isolation, but the way that they connect the image of nature to contemporary historical processes via their contrasting treatments of the visible surface says much about how they relate technology, nature, and the visual. Brecht's ironic disruption of the surface plunges the poetic speaker beneath the waves to show that nature, and by extension any technological or historical constellation that may come to seem natural, is a constructed surface that must be teased apart by the strategies available to the apparatus. For Renger-Patzsch, nature and technology are so linked as elemental forms that they lack any categorical distinction at all; this is a paradoxical and likely conservative logic that obscures the particular social and historical constructedness of each sphere, and yet it is precisely on the formal surface that Renger-Patzsch locates photography's ability to forge a perception adequate to its historical moment.

While Renger-Patzsch was consigned by Benjamin and Brecht to the dustbin of a naïve and retrograde aesthetic realism, a closer look at his photographic theory and practice shows on the contrary just how complex, vexed, and interesting that most simplistic of photography's aspirations and possibilities — namely, the exact mechanical reproduction of the visible surface of things - can be. If photography served RengerPatzsch, Benjamin, and Brecht in various ways to raise the question of a modern aesthetics and an artistic practice adequate to social and technological modernity, we in turn must ask after the relationship between the modern perceptual apparatus that saw and depicted, on the one hand, and the modernity that was to be seen and depicted, on the other. The idea of technology served, in various ways and to varying degrees of conceptual precision, as a focal point and catalyst for these self-consciously 
modern aesthetic and media-theoretical discussions of technologically enhanced vision. In this sense, the ambivalence of the demands made of the photographic image to document reality, train perception, and explore formal variations reflects deeper ambiguities embedded within the very ideas of technology and modernity. The modernity of photography is both the context it is tasked with documenting and the perceptual habits and formal discoveries it instantiates. Both preexisting the medium as its context and produced by it as its aesthetic legacy, "modernity" is on both sides of the camera and the photographic frame, and on neither side.

\section{Notes}

An earlier version of this essay benefited greatly from the patient engagement and rigorous scrutiny of friends and colleagues as part of Cornell's Institute for German Cultural Studies colloquium series in August, 2012. My thanks to all participants, and especially to Ari Linden and Katrina Nousek for their thorough feedback in the context of a later dissertation writing group. Insights, critiques, and suggestions, even where they could not be satisfactorily incorporated into the current article, have nonetheless become part of this project's long-term zymurgy.

1 Bertolt Brecht, Der Dreigroschenprozess. Ein soziologisches Experiment, in Werke. Grosse Kommentierte Berliner und Frankfurter Ausgabe, Schriften I, ed. Werner Hecht, Jan Knopf, Werner Mittenzwei, and Klaus-Detlef Müller (Berlin: Aufbau, 1988), 469. (Note: when a German text is cited, the translation is mine; all other translations used refer to the cited English-language text.)

2. Carl Georg Heise, introduction to Albert Renger-Patzsch, Die Welt ist schön. Einhundert photographische Aufnahmen von Albert Renger-Patzsch, ed. Carl Georg Heise (Munich: Kurt Wolff, 1928), 13-14.

3. Walter Benjamin, "The Author as Producer," in Selected Writings, Volume 2, Part 2: 1931-1934, eds. Michael W. Jennings, Gary Smith, and Howard Eiland (Cambridge, MA: Belknap, 2005), 775 .

4. Albert Renger-Patzsch, "Über die Grenzen unseres Metiers. Kann die Fotografie einen Typus wiedergeben?" ("On the Boundaries of our Metier. Can Photography Reproduce a Type?") in Die Freude am Gegenstand. Gesammelte Aufsätze zur Photographie, eds. Bernd Stiegler, Ann Wilde, and Jürgen Wilde (Munich: Wilhelm Fink, 2010), 222.

5. On the resurgence of the theoretical debate surrounding photography in the 1920s, see Tobias Wilke, Medien der Unmittelbarkeit. Dingkonzepte und Wahrnehmungstechniken 1918-1939 (Munich: Wilhelm Fink, 2010), especially pages 44-47. Additionally, Juliana Kreinik lays out the ways in which the mechanical nature of the camera, the prevalence of technological, industrial subject matter during the 1920s, and the reaction of Neue Sachlichkeit against pictorialist Kunstphotographie all helped make photography understood as a particularly modern medium. Juliana Kreinik, "The Canvas and the Camera in Weimar Germany: A New Objectivity in Painting and Photography of the 1920s" (PhD diss., New York University, 2008), 191.

6. For discussions of how photography was mobilized for discussions of other media, see Matthias Uecker, Wirklichkeit und Literatur. Strategien dokumentarischen Schreibens in der Weimarer Republik (Bern: Peter Lang, 2007), 185-257, and Stefanie Harris, Mediating Modernity: German Literature and the "New" Media, 1895-1930 (University Park: The Pennsylvania State University Press, 2009), 21-53.

7. Kreinik has indicated how the multivalence of the word "Sachlichkeit" factored into discussions of photography during the period, as various possible connotations of truth, evidence, scientific impartiality, everyday subject matter, facticity, the primacy of the object, and pictorial clarity colluded to produce a suggestive if imprecise understanding of art's means and ends. See 
Kreinik, Canvas, 21-22. On the development of Neue Sachlichkeit photography as an "evidentiary aesthetic" that drew on the assumptions, visual codes, and imaging practices of the natural sciences, see Kreinik, Canvas, ch. 4. And in his study of the documentary literature of the Weimar Republic, Matthias Uecker usefully identifies the aesthetic context of the time as one in which the foundational distinction between "truth" ("Wahrheit") and "reality" ("Wirklichkeit") became problematic. Matthias Uecker, Wirklichkeit, 9.

8. For a detailed discussion of the German pictorialist movement of Kunstphotographie in the context of its reception by proponents of Neue Sachlichkeit, see Kreinik, Canvas, 157-204.

9. Albert Renger-Patzsch, "Photographie und Kunst," in Die Freude am Gegenstand. Gesammelte Aufsätze zur Photographie, eds. Bernd Stiegler, Ann Wilde, and Jürgen Wilde (Munich: Wilhelm Fink, 2010), 83.

10. For more on the way that aspects of photography foregrounded in discussions of Neue Sachlichkeit (such as the mechanical nature of the camera, the use of photography as evidence in the natural sciences, and the "innumerable images of industrial technologies, mass-produced commodities, and engineered structures") all contributed to solidifying the associative bonds between photography, technology, and modernity, see Kreinik, Canvas, especially 162-163 and 191.

11. On the narrative structure of Die Welt ist schön, see Michael Jennings, "Agriculture, Industry, and the Birth of the Photo-Essay in the Late Weimar Republic," October 93 (2000): 47. "The volume is organized rather statically into clearly defined groups of images: plants, animals, and humans; landscapes, commodities, architectural details, technological details, and industrial landscapes; and, finally, a last series of ten images that mixes shots from most of the foregoing. Yet sustained consideration reveals connections both within and between groups of images. These connections are only in the rarest of cases thematic. Instead, Renger-Patzsch constellates groups of pictures exclusively through formal rhyming, and these rhymed constellations are almost always self-referential, in that they suggest to the viewer the manner in which the visual information is to be assimilated."

In a somewhat similar vein, Matthew Simms sees the organizing principle of Renger-Patzsch's book in its use of serial and radial structures. Matthew Simms, "Just Photography: Albert RengerPatzsch's Die Welt ist schön," History of Photography 21, no. 3 (1997): 197-204.

12. Bertolt Brecht, "Über Fotografie," ("On Photography”) in Werke. Grosse Kommentierte Berliner und Frankfurter Ausgabe, Schriften I, eds. Werner Hecht, Jan Knopf, Werner Mittenzwei, and Klaus-Detlef Müller (Berlin: Aufbau, 1988), 264.

13. Bertolt Brecht, "[Durch Fotografie keine Einsicht]" (“[No Insight through Photography]"), in Werke. Grosse Kommentierte Berliner und Frankfurter Ausgabe, Schriften I, eds. Werner Hecht, Jan Knopf, Werner Mittenzwei, and Klaus-Detlef Müller (Berlin: Aufbau, 1988), 443-444.

14. Walter Benjamin, "The Author as Producer," 775.

15. Walter Benjamin, "Little History of Photography," in Selected Writings, Volume 2 Part 2: 1931-1934, eds. Michael W. Jennings, Gary Smith, and Howard Eiland (Cambridge, MA: Belknap, 2005), 526.

16. On photography, advertising, and the avant-garde in Weimar Germany see Sherwin Simmons, "Advertising Seizes Control of Life: Berlin Dada and the Power of Advertising," Oxford Art Journal 22, no. 1 (1999): 121-146, and Maud Lavin, "Photomontage, Mass Culture, and Modernity: Utopianism in the Circle of New Advertising Designers," in Montage and Modern Life: 1919-1942, eds. Maud Lavin and Matthew Teitelbaum (Cambridge, MA: MIT Press, 1992), 36-59.

17. "To have a thing painted and put on a canvas is not unlike buying it and putting it in your house. If you buy a painting you buy also the look of the thing it represents. . . . Oil painting did to appearances what capital did to social relations. It reduced everything to the equality of objects. Everything became exchangeable because everything became a commodity. . . . Oil painting celebrated a new kind of wealth-which was dynamic and which found its only sanction in the supreme buying power of money.” John Berger, Ways of Seeing (New York: Penguin, 1977), 83-90. 
18. Karl Marx, Capital Volume I, trans. Ben Fowkes (London: Penguin, 1992), 165.

19. My thanks to Johannes Wankhammer for this particular articulation of the homologous relationship between Verdinglichung and Verklärung.

20. Brecht, Dreigroschenprozess, 469.

21. Benjamin, "Little History," 526.

22. On the contemporary reception of Die Welt ist schön, see Claus Pfingsten, Aspekte zum fotografischen Werk Albert Renger-Patzschs (Witterschlick: M. Wehle, 1992), 168-171.

23. Renger-Patzsch, "Über die Grenzen unseres Metiers," 222.

24. Pfingsten, Aspekte, 114.

25. Bernd Stiegler, Afterword (Nachwort) to Die Freude am Gegenstand, 305.

26. Thomas Janzen, “Albert Renger-Patzsch's Early Work: Object and Abstraction," History of Photography 21, no. 3 (1997): 184.

27. Stiegler, Afterword, 305.

28. Stiegler, Afterword, 305.

29. Bernd Stiegler, "Walter Benjamin und Albert Renger-Patzsch," Hofmannsthal Jahrbuch 17 (2009): 83. Emphasis in original.

30. Renger-Patzsch, "Ziele," in Die Freude am Gegenstand, 91.

31. Renger-Patzsch, "Ziele," 92.

32. Renger-Patzsch, "Photographie und Kunst," 83.

33. Albert Renger-Patzsch, "Ketzergedanken über künstlerische Photographie," in Die Freude am Gegenstand, 47.

34. Renger-Patzsch, "Ketzergedanken," 46.

35. Albert Renger-Patzsch, "Vergewaltigung der Landschaft verboten," in Die Freude am Gegenstand, 130.

36. Albert Renger-Patzsch, "Sylt-Bild einer Insel. Landschaft als Dokument," in Die Freude am Gegenstand, 138.

37. Stiegler, Afterword, 306.

38. On the relationship between Renger-Patzsch and Moholy-Nagy, see Jennings, who reads RengerPatzsch as a major contributor to the avant-garde project: "Always considered the most 'traditional' Weimar photographer, Renger-Patzsch instead emerges here as a major modernist; in fact, only Moholy merits comparison.” Jennings, "Agriculture," 47.

39. As Renger-Patzsch would write in 1937, "I believe I can rightly say that back then I wanted this book to be understood much less in a philosophical sense (as was often falsely concluded from the title) than in a didactic sense, as an ABC-book that should show how one could reach pictorial solutions in a purely photographic way, and that the charms of photography are anchored in the continuous tone, in the distribution of surfaces, and in the course of lines. These photographs consciously display the charm of the surface." Albert Renger-Patzsch, "[Beitrag zu:] Meister der Kamera Erzählen," in Die Freude am Gegenstand, 150.

40. For more on the role of visibility in Brecht, especially as it relates to defamiliarization, see Steve Giles, "Making Visible, Making Strange: Photography and Representation in Kracauer, Brecht and Benjamin," New Formations: A Journal of Culture/Theory/Politics 61 (2007): 65-75.

41. The best known example is almost certainly in the artwork essay, where Benjamin describes the perceptual access granted by both the still and the cinematic camera in terms of the "dynamite of the tenth of a second" and the totally new structures that come to light under magnification. Walter Benjamin, "Das Kunstwerk im Zeitalter seiner mechanischen Reproduzierbarkeit" ("The Work of Art in the Age of Its Mechanical Reproduceability"), in Gesammelte Schriften, Band I, eds. Rolf Tiedemann and Hermann Schweppenhäuser (Frankfurt am Main: Suhrkamp, 1972), 499-500.

42. Walter Benjamin, "Neues von Blumen" ("New Things about Flowers"), in Gesammelte Schriften, Band III, eds. Rolf Tiedemann and Hermann Schweppenhäuser (Frankfurt am Main: Suhrkamp, 1972), 151. 
43. Benjamin, "Neues von Blumen," 152.

44. Benjamin, "Neues von Blumen," 153. Note that the German word "Kelch" used by Benjamin means both "chalice" and "calyx," a poetic ambiguity that suggests that the "sonnenhafte Augen" of Goethe and Herder may well have been compound.

45. Albert Renger-Patzsch, "Das Photographieren von Blüten," in Die Freude am Gegenstand, eds. Bernd Stiegler, Ann Wilde, and Jürgen Wilde (Munich: Wilhelm Fink, 2010), 17. To be sure, there are important differences between these two passages. Benjamin's claim is in one respect more modest, since a fully adequate vision of the world of plant forms and their analogies is reserved for "Riesengeister," where Renger-Patzsch implies that anyone can learn to see with the eyes of insects and be at home in their world. Yet what matters most in this context is that photography in both quotes inhabits a drastic change of scale from everyday perception, defamiliarizing the visible world. This commonality demonstrates larger perceptual and experiential claims made in the name of photography that are compelling even though, for example, Blossfeldt's work relied on extreme magnification while Renger-Patzsch's photographs can seem almost claustrophobically confined to an everyday angle of focus.

46. "In the bishop's staff represented by an ostrich fern, in the larkspur and the blossom of the saxifrage, which also does honor to its name as a rose window on cathedrals, as it pierces through the walls, one senses a Gothic parti pris. Besides this of course, there appear in the horse tail the oldest columnar forms, in the chestnut and maple shoot totem poles], and the shoot of the monkshood* unfolds like the body of a gifted dancer." *In the original, the word used for this plant is "Eisenhuf," which is likely a misprint for "Eisenhut." Benjamin, "Neues von Blumen," $152-153$.

47. In Walter Benjamin, Gesammelte Schriften Band IV, eds. Rolf Tiedemann and Hermann Schweppenhäuser (Frankfurt am Main: Suhrkamp, 1972), 730. For a closer reading of this convergence of imagery, see Stiegler, "Albert Renger-Patzsch und Walter Benjamin," 71-82.

48. On Brecht's, Benjamin's, and Kracauer's reactions to the contemporary discourse of photographic verisimilitude, see McBride: “As it has by now become clear, neither Kracauer's nor Brecht's indictment of the use of photographs in the press is driven by a traditional distrust of mimesis, that is, by the age-old wariness toward reproducing the world of appearances, which is repudiated for being a deceptive veil cast on the true essence of things. Rather, they are animated by awareness that photography's potential does not lie in its ability to reproduce appearances in an exact way." Patrizia McBride, "Narrative Resemblance: The Production of Truth in the Modernist Photobook of Weimar Germany," New German Critique 39, no. 1, issue 115 (2012): 174.

49. One characteristic of the New Vision photography of the 1920s was that, as formulated by Kreinik, "mechanisms of modern technology were both the subject and object of visual representation." Kreinik, Canvas, 11.

50. Brecht, Dreigroschenproze $\beta, 468$.

51. Brecht, Dreigroschenproze $\beta, 480-481$.

52. Bertolt Brecht, "Fotografie," in Werke. Grosse Kommentierte Berliner und Frankfurter Ausgabe, Schriften I, eds. Werner Hecht, Jan Knopf, Werner Mittenzwei, and Klaus-Detlef Müller (Berlin: Aufbau, 1988), 265

53. Brecht, Dreigroschenprozess, 469.

54. Benjamin, "Little History," 526.

55. As Stefan Soldovieri argues, "all of Brecht's reflections on photography involve drawing attention to the concealed 'irritation' of the camera in an effort to destroy the image's apparent innocuousness." Stefan Soldovieri, "War-Poetry, Photo(epi)grammetry," in A Bertolt Brecht Reference Companion, ed. Siegfried Mews (Westport, CT: Greenwood, 1997), 146.

56. Brecht, Dreigroschenproze $\beta, 469$.

57. On the ambiguity of Beschriftung as a political-aesthetic practice, see Matthias Uecker, "The Face of the Weimar Republic: Photography, Physiognomy, and Propaganda in Weimar Germany," 
Monatshefte für Deutschsprachige Literatur und Kultur 99, no. 4 (2007): 477. On the relationship between the images and captions in Kriegsfibel, see J.J. Long, "Paratextual Profusion: Photography and Text in Bertolt Brecht's War Primer," Poetics Today 29, no. 1 (2008): 197-224.

58. "This is the first of a series of metaphors emphasizing the need for Brecht's sociological experiment to make social realities visible, 'um das zu sehende jedermann sichtbar zu machen' ['to make that which is to be seen visible to everyone']." Steve Giles, Bertolt Brecht and Critical Theory: Marxism, Modernity, and the Threepenny Lawsuit (Bern: P. Lang, 1997), 74.

59. Brecht, Dreigroschenproze $\beta, 469$.

60. Sabine Hake, "Faces of Weimar Germany," in The Image in Dispute: Art and Cinema in the Age of Photography, ed. Dudley Andrew (Austin: University of Texas Press, 1997), 117-147. Matthias Uecker, "The Face of the Weimar Republic. Photography, Physiognomy, and Propaganda in Weimar Germany," Monatshefte 99, no. 4 (2007): 469-484. On the broader physiognomic discourse in Weimar Germany, see Richard Gray, About Face: German Physiognomic Thought from Lavater to Auschwitz (Detroit: Wayne State University Press, 2004), 177-217.

61. Matthew Simms has argued quite compellingly that Benjamin's objection to Renger-Patzsch can be located in a suspicion of an ontology of the copula linked to Heidegger. I agree with the basic contours of the critique he reconstructs with Renger-Patzsch, Benjamin, Adorno, Heidegger, and Bataille as key figures, but do not quite accept his conclusion: "that in Die Welt ist schön photography and ontology coincide. The question 'What is photography?', therefore, receives from Renger-Patzsch the tautological answer that photography is precisely the 'is'; or put less gnomically, photography is identified here with the power to recover certainty and solid ground in a world disturbingly off balance." Matthew Simms, "Just Photography," 197-204.

62. Bertolt Brecht, War Primer, trans. John Willett (London: Libris, 1998), 7. Translation modified. 


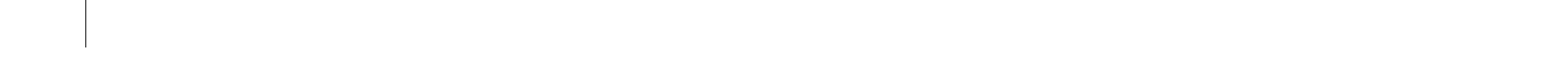

